\title{
Impact of Job Involvement on In-Role Job Performance and Organizational Citizenship Behaviour
}

\author{
Aamir Ali Chughtai \\ Dublin City University \\ Ireland
}

\begin{abstract}
This study examines the impact of job involvement on the self-report measures of inrole job performance and organizational citizenship behaviour. The results of this study revealed that job involvement was positively correlated with both in-role job performance $(r=0.30, p<0.01)$ and OCB $(r=0.43, p<0.01)$. In addition to this it was found that organizational commitment partially mediated the job involvementperformance relationship. Furthermore the findings of this research uncovered that job involvement exerted a stronger impact on OCB than on in-role performance. Finally the practical implications of this research for organizations are discussed.
\end{abstract}

\section{Introduction}

Job involvement has been defined as an individual's psychological identification or commitment to his / her job (Kanungo, 1982a). It is the degree to 'which one is cognitively preoccupied with, engaged in, and concerned with one's present job (Paullay et al., 1994, p. 224). Job involvement involves the internalisation of values about the goodness of work or the importance of work in the worth of the individual (Lodahl \& Kejner, 1965). As such individuals who display high involvement in their jobs consider their work to be a very important part of their lives and whether or not they feel good about themselves is closely related to how they perform on their jobs. In other words for highly involved individuals performing well on the job is important for their self esteem (Lodahl \& Kejner, 1965). Because of this people who are high in job involvement genuinely care for and are concerned about their work (Kanungo, 1982b).

The construct of job involvement is somewhat similar to organizational commitment in that they are both concerned with an employee's identification with the work experience. However the constructs differ in that job involvement is more closely associated with identification with one's immediate work activities whereas organizational commitment refers to one's attachment to the organization (Brown, 1996). It is possible for example to be very involved in a specific job but not be committed to the organization or vice versa (Blau \& Boal, 1987).

Research studies over the past two decades, which have explored the construct of job involvement, have approached it from two different perspectives (Sekeran, 1989; Sekeran \& Mowday, 1981). First when viewed as an individual difference variable, job involvement is believed to occur when the possession of certain needs, values or personal characteristics predispose individuals to become more or less involved in their jobs. For instance Rabinowitz and Hall (1977) in their review of literature on job involvement found that individual characteristics such as age, education, sex, tenure, need strength, level of control and values were linked to job involvement. The second perspective views job involvement as a response to specific work situation characteristics. In other words certain types of jobs or characteristics of the work situation influence the degree to which an individual becomes involved in his / her job. For example research has demonstrated that job involvement has been related to job characteristics such as task autonomy, task significance, task identity, skill variety and feedback and supervisory behaviours such as leader consideration, participative decision making and amount of communication (Brown, 1996). 
Fostering job involvement is an important organizational objective because many researchers consider it to be a primary determinant of organizational effectiveness (Pfeffer, 1994) and individual motivation (Hackman \& Lawler, 1971). These links stem from the theoretical notion that being immersed in one's work increases motivational processes which in turn influence job performance and other relevant outcomes like turnover and absenteeism (Diefendorff et al., 2002).

\section{Present Study}

Although job involvement is considered to be a key factor influencing important individual and organizational outcomes (Lawler, 1986), research finding a significant impact of this construct on performance has met limited success (Brown, 1996; Diefendorff et al., 2002). The general perception is that people with high levels of job involvement are likely to put more effort into their jobs and therefore tend to display higher levels of in-role performance. Although research on job involvement provides some support for this notion (e.g. Cron 1984; Dubinsky and Hartley, 1986; Brown \& Leigh, 1996), generally the results have been disappointing. For example summarizing the available empirical evidence to date, Brown's (1996) meta-analysis estimated the population correlation between overall performance and job involvement to be nonsignificant. Although job involvement, did have a significant estimated population correlation with 'combination measures' of performance, the coefficient was quite small. Brown and Leigh (1996) suggest that the reason for this weak relationship maybe that instead of exerting a direct influence, job involvement is more likely to affect performance indirectly through other variables like effort.

Therefore the central aim of this research is to examine the relationship between job involvement and in-role and extra- role (OCB) performance. This research will not only examine the direct effect of job involvement on in-role job performance but will also study its indirect effect via organizational commitment. More specifically this research posits that organizational commitment would mediate the relationship between job involvement and in-role performance.

The second objective of this study is to find if job involvement is related to organizational citizenship behaviour. Surprisingly the relationship between job involvement and OCB has received very little empirical attention (Rotenberry and Moberg, 2007). The present study therefore aims to extend the literature by examining the effects of job involvement on OCB.

Finally this research would examine the relative effects of job involvement on in-role job performance and organizational citizenship behaviour. More specifically this study would attempt to find whether job involvement exerts a stronger impact on in-role performance or organizational citizenship behaviour.

\section{Literature Review \& Hypotheses Development}

\section{Job Involvement and In-Role Job Performance}

In- role job performance refers to activities that are related to employees' formal role requirements (Borman \& Motowidlo, 1997). Generally it is believed that job involvement by positively affecting employees' motivation and effort, leads to higher levels of in-role job performance (Brown, 1996). Prior research has indicated some support for this claim. For instance Brown and Leigh (1996) in their study found that job involvement had both direct and indirect effects via effort on performance. More specifically they found that the modest but statistically significant relationship between job involvement and performance became non significant when effort was inserted into the model, indicating the mediating effect of effort on the relationship. 
Lassak et al. (2001) argued that occupation specific measures of job involvement should be created and consequently developed a measure of 'salesperson job involvement'. Their study uncovered a significant but positive relationship between one facet of their measure, 'relationship' involvement and performance.

Using a measure created by Paullay et al. (1994), to differentiate job involvement from work centrality, Diefendorff et al., (2002) found a small but significant correlation ( $r=$ $0.19, p<0.05)$ between job involvement and supervisor - rated in-role performance.

Finally Rotenberry and Moberg (2007), using the same measure of job involvement as Diefendorff et al., (2002), reported a small but significant positive correlation $(r=0.15$, $\mathrm{p}<0.05)$ between job involvement and in-role performance.

Although generally the results concerning the relationship between job involvement and performance have not been very encouraging there is evidence to suggest that job involvement can positively influence in-role job performance. Thus in light of the research evidence cited above it is hypothesised that job involvement would be positively correlated with in-role performance.

H1: There will be a significant positive correlation between job involvement and inrole performance.

\section{The Mediating Role of Organizational Commitment}

Brown and Leigh (1996) argue that one reason for the weak and inconsistent relationship between job involvement and performance may be that job involvement is more likely to affect performance indirectly through other variables. This study posits that organizational commitment would link job involvement with performance. In the present study organization commitment has been defined as the relative strength of an individual's identification with and involvement in a particular organization (Mowday, Steers and Porter, 1982). The authors mention three characteristics of organizational commitment: (1). a strong belief in and acceptance of the organization's goals and values, (2) a willingness to exert a considerable effort on behalf of the organization and (3) a strong intent or desire to remain with the organization. It is argued that job involvement will first lead to commitment, which in turn will lead to higher levels of performance. The relationship between job involvement and organizational commitment is well documented in the literature (Janis, 1989; Loui, 1995; Brown, 1996). The positive relationship between job involvement and commitment suggests that those employees who are committed to their jobs are also likely to be committed to their employing organizations.

Similarly research has indicated that organizational commitment is positively related to job performance (e.g. Meyer et.al., 1989; Konovsky \& Cropanzano, 1991). This finding posits that employees who are committed to their organizations are more likely not only to remain with the organization but are also likely to exert more effort on behalf of the organization and work towards its success and therefore should be better performers than the uncommitted employees.

Taken together this discussion implies that job involvement would foster organizational commitment among employees and committed employees in turn would put in extra effort on behalf of their organization, which consequently would lead to higher levels of performance. In other words organizational commitment would mediate the relationship between job involvement and performance.

H2: Organizational commitment would mediate the relationship between job involvement and in-role job performance. 
According to Katz and Kahn (1978), effective organizational functioning requires employees to not only perform their prescribed role, but also to engage in behaviours that go beyond these formal obligations. This aspect of performance is consistent with Organ's (1988) conceptualizations of OCBs. Organizational citizenship behaviours (or OCB's) are discretionary workplace behaviours that exceed one's basic job requirements. They are often described as behaviours that "go above and beyond the call of duty." OCB's have been defined as "individual behaviours that are discretionary, not directly or explicitly recognized by the formal reward system, and that in aggregate promote the effective functioning of an organization" (Organ, 1988). Such behaviours are said to "lubricate the social machinery of the organization" (Bateman and Organ, 1983). Examples of OCB include acts of helpfulness, gestures of goodwill and cooperation among organizational members. OCB benefits organizations in a number of ways. According to Cohen and Vigoda (2000) some of the benefits of OCBs that can accrue to an organization include: (a) improved co-worker and managerial productivity, (b) superior efficiency in resource use and allocation, (c) reduced maintenance expenses, and (d) improved organizational attractiveness for high-quality new recruits.

The relationship between job involvement and OCB's has unfortunately received scant empirical attention. An examination of the literature revealed that until recently only Munene (1995) and Somers and Birnbaum (1998) had even considered this relationship. Both these authors found a significant correlation between job involvement and OCB. More recently research studies conducted by Diefendorff et al. (2002), Bolger and Somech (2004), Chu et al (2005) and Rotenberry and Moberg (2007) have also uncovered a positive relationship between job involvement and OCB. Given the fact that OCBs are more influenced by what individuals think and feel about their jobs (Organ \& Ryan, 1995) and that job involvement reflects a positive attitude towards the job, it follows that those high in job involvement would engage in these behaviours to a greater extent than less involved individuals. The review of the above mentioned studies reveals that job involvement directly effects organizational citizenship behaviour. Thus the present study also hypothesises that there would be a direct and positive relationship between job involvement and organizational citizenship behaviours.

H3: There will be a significant positive correlation between job involvement and organizational citizenship behaviours.

\section{The Relative Effects of Job Involvement on In-Role Job Performance and Organizational Citizenship Behaviours}

Diefendorff et al. (2002) and Somers and Birnbaum (1998) suggest that because OCB's are more discretionary than in-role prescribed duties, employees attitudes and beliefs should have a greater impact on them. Diefendorff et al. (2002) asserted that completing in-role tasks is often constrained by rules and environmental conditions at work whereas OCBs are under the volitional control of the individual employee. Because of this employee attitudes such as job involvement ought to have a larger impact upon the execution of OCBs rather than in-role performance. Consequently it is hypothesised that job involvement would have a greater impact on OCB than on in-role performance.

H4: Job involvement would have a greater impact on OCB than on job performance. 


\section{Methodology}

\section{Sample}

For this study data was collected from full time faculty members teaching in 53 universities operating in five major cities of Pakistan: Lahore, Islamabad / Rawalpindi, Peshawar, Karachi and Quetta. For the present study a sample of university teachers was selected because within the context of the Pakistani job market this is an under researched area and it was believed that this study would provide useful guidelines to education managers in Pakistan to increase the performance of faculty members through interventions designed to increase job involvement. The sample was taken from the five major cities of Pakistan mentioned above because all the major educational institutions in the country are located within these cities.

In order to select a representative sample for this study I utilized the stratified random sampling technique. Three steps are involved in stratified random sampling. The first step requires the determination of the overall sample size. In the second step the total sample size is allocated among different strata and in the third step the required number of respondents is chosen from each strata using random sampling. Three factors were considered to determine the sample size: (1) the degree of variability in the population; (2) magnitude of acceptable error; and (3) confidence level to ensure that the estimates would remain within the range of acceptable error (Zikmund, 2003).

The main problem encountered in the estimation of the sample size was the nonavailability of the population standard deviation (i.e. an estimate of the degree of variability in the population). In order to find the estimate of the standard deviation, I conducted a pilot study by selecting a sample of teachers from four universities. From the results of the pilot study the estimate of the population standard deviation was calculated. By assuming a 99\% confidence interval and the magnitude of acceptable error of 2 the total sample size was determined. The reason for choosing a $99 \%$ confidence interval and the magnitude of standard error of 2 was to keep the sample size within manageable limits owing to the cost and time constraints. The total sample size with these specifications came out to be 208 .

Next, I divided my total population into five strata on basis of cities, with each city included in the sampling procedure considered as a separate stratum. The total sample size of 208 teachers (out of a total of 6,488 teachers) was then proportionally distributed among the five cities. Finally the required number of respondents from each stratum was selected by simple random sampling.

\section{Data Collection Procedure}

The required number of questionnaires and the accompanying cover letter assuring confidentiality was handed over to the research officer in the Centre for Statistics at the Lahore School of Economics. The research officer then visited the selected respondents at their respective institutions and cities and requested them to fill the questionnaires. If the respondents had the time they filled the questionnaire on the spot. In other cases the research officer dropped the questionnaire with the relevant respondents and collected the questionnaire at a mutually agreed date and time. Participation in this survey was completely voluntary. It took about eight weeks to collect the data.

Data were collected from Lecturers, Assistant Professors, Associate Professors and Full Professors teaching on a full time basis in the participating universities. Out of a total of 208 questionnaires, which were distributed, 195 were completed and returned thereby yielding a response rate of $93.8 \%$. One reason for this high response rate was that the respondents were approached personally at their workplace by the research officer. If 
the questionnaires were sent through mail, it is speculated that the response rate would have been much lower.

\section{Sample Characteristics}

The sample of employees was 64 percent male and 36 percent female. The male to female ratio obtained for the present sample was quite representative of the total population of faculty members because it was found that out of a total of 6488 teachers teaching in the five cities surveyed, about $72 \%$ were male and $28 \%$ were female. Ten percent of the faculty members belonged to the faculty of arts, $21 \%$ percent were from the faculty of social and environmental sciences, approximately $57 \%$ taught in the faculty of science and engineering and about $11 \%$ belo nged to the faculty of business and management. A total of 72 percent of the sample was married. The average age and job tenure for the sample was 39 and 9 years respectively.

\section{Measurement of Variables}

\section{Organizational Commitment}

Organizational commitment was measured by Organizational Commitment Questionnaire (OCQ) developed by Modway, Steers and Porter, (1982). They created the OCQ by identifying 15 factors that could be correlated with their definition of organizational commitment: (1) a strong belief in and acceptance of the organization's goals and values; (2) a willingness to exert considerable effort on behalf of the organization; (3) a strong desire to maintain membership in the organization. Each item of this instrument asked for agreement or disagreement on a seven point Likert scale ranging from "Strongly Disagree"(weighted 1) to "Strongly Agree" (weighted 7), with a statement, which tapped the organizational commitment construct. The average of the 15 items was used as the total scale score for each respondent. The organizational commitment questionnaire has been widely used in previous studies to measure commitment and has demonstrated both convergent and discriminant validity (Huselid \& Day, 1991). As a consequence this instrument was adopted in the present study to measure commitment. The value of coefficient alpha for this scale in the present sample was 0.80 .

\section{$\underline{\text { Job Involvement }}$}

Job involvement was measured by 12 items taken from the job involvement scale developed by Lodahl and Kejner (1965). Each item was measured on a five-point scale where a value of one corresponded to "Strongly Disagree" and a value of 5 corresponded to "Strongly Agree". The scores obtained on each of the 12 items were averaged to produce a single score for job involvement. Brown (1996) on the basis of his meta-analytic study contends that the job involvement scale developed by Lodahl and Kejner (1965) is a reliable and useful measure of job involvement and as a result this scale was utilized to measure the construct of job involvement in the present study. The value of coefficient alpha for this sample was 0.71 .

\section{$\underline{\text { In-Role Performance }}$}

In-role performance was measured by using a self-appraisal approach. For this purpose I designed a self-appraisal form, which required the respondents to rate their performance on five dimensions, which were included on the basis of the results from preliminary interviews conducted with faculty members prior to administrating the survey. These dimensions included: teaching ability, interpersonal skills, communication skills, student advisement and consultation and personal initiative. In North America and Europe, faculty are primarily evaluated on the basis of number of research publications and student ratings of the faculty member's teaching (Skarlicki \& Latham, 1995). 
However in Pakistani universities research publications is not a requirement for faculty members and as a result this dimension was not included as a measure of performance. As far as student ratings of faculty members were concerned, the universities included in the present survey were reluctant to divulge this information and as a consequence this aspect of faculty performance could not be included in this study.

Each dimension was measured by a single statement and the responses were obtained on a seven-point scale where a value of one corresponded to "Strongly Disagree" and a value of 7 corresponded to "Strongly Agree". The scores obtained on each of the five items were averaged to produce a summary score reflecting in-role performance. The method of self-appraisal has been used in previous research (e.g. Ashforth and Saks, 1996; Yousef, 1998) and has produced satisfactory results. The coefficient alpha of this sample was 0.78 .

\section{Organizational Citizenship Behaviour}

Organizational citizenship behaviour was measured by 13 items extracted from the Chinese citizenship behaviour scale developed by Farh, Earley and Lin (1997) and the OCB scale developed by Podsakoff et al (1990). Items from Farh et al.'s (1997) Chinese citizenship scale were included in the OCB scale for the present study because OCBs in the Chinese society seem to correspond with OCBs in the Pakistani society. This is because Pakistan is culturally close to China in the sense that like China, Pakistan is also high on collectivism and power distance.

Each item in the scale was measured on a five-point scale where a value of one corresponded to "Strongly Disagree" and a value of 5 corresponded to "Strongly Agree". The scores obtained on each of the 13 items were averaged to produce a single score for organizational citizenship behaviour. The coefficient alpha of this sample was 0.89 .

\section{Control Variables}

Two control variables included in this study were: age and gender. These variables were measured as follows:

\section{$\underline{\text { Age }}$}

The respondents were requested to report their age in years as of their last birthday.

\section{Gender}

Respondents were asked to report their gender. In the data compilation, gender was coded as follows: male $=1$ and female $=0$.

\section{Results}

Table 1 shows the means, standard deviations, reliabilities and zero-order correlations of the variables used in this study. The overall mean (Mean $=4.13, S D=0.42$ ) for job involvement was reasonably high. The respondents reported moderately high levels of organizational commitment (Mean $=5.27, \mathrm{SD}=0.84$ ). The high mean for OCB (Mean = $4.24, S D=0.51$ ) indicated that the respondents frequently engaged in performing OCBs. In addition, the subjects rated their in-role performance very highly (Mean $=6.32, \mathrm{SD}=$ 0.70 ). Finally the average age for this sample was 39 years.

The reliabilities for all the multi-item scales were generally very good. All alpha values met the criterion of 0.70 proposed by Nunnaly \& Bernstein (1994). The alpha values ranged from 0.71 to 0.89 for the present sample. 
Table 1

Descriptive Statistics, Alpha Reliabilities, and Correlations among Study Variables $(\mathrm{N}=\mathbf{1 9 5})$

\begin{tabular}{|l|l|l|l|l|l|l|l|}
\hline Variable & Mean & SD & $\mathbf{1}$ & $\mathbf{2}$ & $\mathbf{3}$ & $\mathbf{4}$ & $\mathbf{5}$ \\
\hline 1.Job Involvement & 4.13 & 0.42 & $\mathbf{( 0 . 7 1 )}$ & & & & \\
\hline 2.In-role Performance & 6.32 & 0.70 & $0.30^{\star \star}$ & $\mathbf{( 0 . 7 8 )}$ & & & \\
\hline 3.OCB & 4.24 & 0.51 & $0.43^{\star \star}$ & $0.64^{\star \star}$ & $\mathbf{( 0 . 8 9 )}$ & & \\
\hline 4.Organizational Commitment & 5.27 & 0.84 & $0.22^{\star \star}$ & $0.27^{\star \star}$ & $0.38^{\star \star}$ & $\mathbf{( 0 . 8 0 )}$ & \\
\hline 5. Age & 39 & 11.28 & 0.11 & 0.10 & 0.07 & 0.14 & \\
\hline 6. Gender & & & 0.031 & -0.05 & -0.06 & -0.09 & 0.11 \\
\hline
\end{tabular}

${ }^{*}$ Correlation is significant at the 0.01 level; Cronbach alpha reliabilities for observed variables are in parenthesis in the diagonal.

The correlation matrix in Table 1 also demonstrates that job involvement is significantly and positively correlated with self-report measures of in-role performance $(r=0.30$, $p<0.01)$ and OCB $(r=0.43, p<0.01)$. These findings support hypotheses one and three.

Hypothesis two posits that organizational commitment would mediate the relationship between job involvement and in-role job performance. To test this hypothesis I followed Baron and Kenny's (1986) recommendations for examining mediating effects in regression. They argued that mediation is demonstrated if three conditions are fulfilled: The first condition stipulates that the independent variable and the proposed mediator must each be significantly related to the dependent variable when considered separately. The correlation analysis presented in Table 1 reveals that the independent variable (job involvement) was significantly related to the dependent variable (in-role job performance) independent of the proposed mediator (organizational commitment). To determine whether the proposed mediator was related to the dependent variable, the correlation matrix in Table 1 was again examined. From Table 1 it was observed that organizational commitment was positively and significantly correlated with the selfreport measure of in-role performance $(r=0.27, p<0.01)$. Therefore the first condition for mediation was satisfied.

The second condition requires that the independent variable to be significantly related to the proposed mediator. From the correlation matrix in Table 1 it can be seen that job involvement is positively and significantly related with organizational commitment $(r=$ $0.22, p<0.01)$. Hence the second condition for mediation is also satisfied.

The last condition for mediation stipulates that when both the independent variable and mediator are included in a regression equation, the direct relationship between the independent variable and the dependent variable should become significantly smaller, indicating partial mediation, or non-significant, indicating full mediation. To test this last condition I utilized the hierarchical multiple regression technique. Table 2 shows the results.

When in-role job performance was regressed on job involvement, it was found that job involvement was significantly and positively related to performance. In step 2 organizational commitment was added to the equation, and organizational commitment was significant, but job involvement also remained significant, although its beta weight decreased from $b=0.295$ to $b=0.248$. Taken together these results imply that organizational commitment partially mediated the relationship between job involvement and the self-report measure of in-role performance. Thus hypothesis two is partially supported. 
Table 2

Hierarchical Regression examining the mediating effects of organizational commitment on the job involvement - performance relationship

\begin{tabular}{|c|c|}
\hline Independent & In-role job \\
\hline & $\begin{array}{l}\text { Standardized } \\
\text { Coefficients }\end{array}$ \\
\hline \multicolumn{2}{|l|}{ Step 1} \\
\hline $\begin{array}{l}\text { Job } \\
\text { Involvement }\end{array}$ & $0.295^{\star *}$ \\
\hline $\mathrm{R}^{2}$ & 0.087 \\
\hline Change in $R^{2}$ & 0.087 \\
\hline F- change & $18.45^{\star \star}$ \\
\hline \multicolumn{2}{|l|}{ Step 2} \\
\hline $\begin{array}{l}\text { Job } \\
\text { Involvement }\end{array}$ & $0.248^{* *}$ \\
\hline $\begin{array}{l}\text { Organizational } \\
\text { Commitment }\end{array}$ & $0.217^{\star \star}$ \\
\hline $\mathrm{R}^{2}$ & .132 \\
\hline Change in $\mathrm{R}^{2}$ & 0.045 \\
\hline F- change & $9.906^{* *}$ \\
\hline
\end{tabular}

Finally hypothesis four states that job involvement would have a stronger impact on OCB than on in-role job performance. In order to test this hypothesis, I proceeded by examining the incremental increase in regression $R^{2}$ when job involvement was entered into the regression models following the two control variables - gender and age. For this purpose, separate two-step, hierarchical regression analyses were performed for in-role performance and OCB respectively. At step one I entered the two control variables, gender and age as a block. As Table 3 shows, both age and gender were found to be unrelated to the self-report measures of in-role performance and OCB. These demographic variables alone explained only about 1 percent and 0.9 percent of the variance in in-role performance and OCB respectively.

In step two I entered job involvement. With the two demographic variables controlled, job involvement accounted for an additional 8 percent of the variance in in-role performance and an additional 18 percent of the variance in OCB. Since the increase in the value of $R^{2}$ was substantially larger for OCB when job involvement was added to the control variables, it was concluded that job involvement exerted a stronger impact on OCB than on in-role performance. Thus hypothesis four was substantiated. These results are shown in table 3. 
Table 3

Hierarchical Regression examining the relative effects of job involvement on inrole performance and $\mathrm{OCB}$

\begin{tabular}{|l|l|l|}
\hline $\begin{array}{l}\text { Independent } \\
\text { Variables }\end{array}$ & $\begin{array}{l}\text { In-role } \\
\text { performance }\end{array}$ & OCB \\
\hline Coefficients & $\begin{array}{l}\text { Standardized } \\
\text { Coefficients }\end{array}$ \\
\hline Step 1 & & \\
\hline Gender & -0.058 & -0.064 \\
\hline Age & 0.109 & 0.079 \\
\hline $\mathrm{R}^{2}$ & 0.014 & 0.009 \\
\hline Change in $\mathrm{R}^{2}$ & 0.014 & 0.009 \\
\hline F-change & 1.342 & 0.888 \\
\hline Step 2 & & $0.428^{* *}$ \\
\hline $\begin{array}{l}\text { Job } \\
\text { Involvement }\end{array}$ & $0.289^{* *}$ & 0.19 \\
\hline $\mathrm{R}^{2}$ & 0.096 & 0.181 \\
\hline Change in $\mathrm{R}^{2}$ & 0.082 & $42.57^{\star *}$ \\
\hline $\mathrm{F}-$ change & $17.43^{\star *}$ & \\
\hline \multirow{2}{**}{$\mathrm{p}<0.01$} & &
\end{tabular}

\section{Discussion}

This study reaffirms job involvement as a potentially important determinant of individual performance. Although studies examining the relationship between job involvement and performance have by and large produced disappointing results, the findings of this research supports the notion that highly involved employees tend to perform at higher levels. People who are highly involved in their work tend to be more motivated and consequently are likely to put in more effort into their jobs and therefore should perform better than less involved individuals (Brown and Leigh, 1996).

The findings of this study show that job involvement not only affects performance directly but also indirectly by enhancing organizational commitment. The results of this study revealed that commitment partially mediated the job involvement-performance relationship. People who are very involved in their job and for whom their job is a 'central life interest' (Rabinowitz \& Hall, 1977) - that is the job is a major source for satisfaction of important needs - will have less of an incentive to leave their current organization and seek employment elsewhere and as a consequent would be more committed to their organizations. The relationship between job involvement and commitment is well supported in the literature (e.g. Loui, 1995; Brown, 1996).

Committed employees in turn put in extra effort to contribute towards the success of the organization, which consequently leads to higher performance (Meyer et al. 1989). The results of this study indicate that commitment is significantly and positively related to both in-role $(r=0.27, p<0.01)$ and extra-role performance $(r=0.38, p<0.01)$. It follows that interventions aimed at simultaneously increasing job involvement and organizational commitment can be a potent method to increase both types of performance.

The results of this study also show that job involvement is positively correlated with OCB. This result supports the findings reported by Diefendorff et al. (2002), Bolger and Somech (2004), Chu et al (2005) \& Rotenberry and Moberg (2007), who also uncovered a positive relationship between job involvement and OCB in their respective studies. Given the fact OCBs are more influenced by what individuals think and feel about their jobs (Organ \& Ryan, 1995) and that job involvement reflects a positive attitude towards the job, it follows that those high in job involvement would engage in these behaviours 
to a greater extent than less involved individuals. In addition, the social exchange theory (Blau, 1964) may also be applied to explain the relationship between job involvement and OCB. Specifically employees feel indebted for the needs satisfaction, resulting in job involvement, that their organization provides and subsequently feel obligated to reciprocate (e.g. Cohen, 1999, 2000). Employees may reciprocate to this needs satisfaction by engaging in more organizational citizenship behaviours for their organizations.

Finally in this study it was found that job involvement exerted a stronger impact on OCB than on in-role performance. Rotenberry and Moberg (2007) also found the same result in their study. Somers and Brinbaum (1998) and Diefendorff et al. (2002) each argued that in-role performance is often constrained by factors outside of the employee, while engaging in citizenship behaviour is generally under the employee's control. Because of this employee attitudes such as job involvement ought to have a larger impact upon the execution of OCBs rather than in-role performance.

\section{Implications for Managers and Organizations}

The findings of this research have important implications for managers and their organizations. The results of this research demonstrate that job involvement is a potent weapon to increase both in-role and extra role (OCBs) performance. In addition to having positive affects on performance, prior research has found that job involvement positively influences other attitudinal and behavioural outcomes such as organizational commitment (Brown, 1996), turnover (Huselid and Day, 1991) and absenteeism (Harrison \& Martocchio, 1998). On the contrary low levels of job involvement contribute to employees' feelings of alienation of purpose, alienation in the organization or feeling of separation between what the employees see as their 'life' and the job they do (Rabinowitz \& Hall, 1981). Thus fostering high levels of job involvement is a viable option for managers to increase the competitive position of their organizations. The question is that how can managers increase the levels of employees' job involvement? Research has demonstrated that by re-designing jobs through the incorporation of job characteristics, such as autonomy, feedback, variety and task identity, management can make jobs more interesting, meaningful and challenging for job incumbents which in turn can lead to higher job involvement (Rainowitz and Hall, 1977; Saal, 1978; Knoop 1986). Brown (1996) in his review of the organizational research on job involvement concludes that work environments that (a) provide a sense of meaningfulness to one's work, (b) offer control over the methods by which work is accomplished, (c) maintain clear and consistent behavioural norms, (d) provide feedback about the work accomplished, (e) include supportive relation with superiors and co-workers and (f) offer opportunities for personal growth and development are conducive to job involvement. Taken together this discussion implies that organizations can reap the positive benefits of job involvement by providing resources to employees at the level of the task (e.g. skill variety, task significance, task identity, autonomy and feedback), interpersonal and social relations (e.g. supervisor and co-worker support), organization of work (e.g. participation in decision making) and at the level of the organization at large (e.g. career opportunities).

\section{Limitations of the Study}

Although the findings of this study are useful, it is limited by several factors. One limitation of this study is that it uses the self-report measures of in-role performance and OCB. If the data on in-role performance and OCB were collected from supervisors or peers of the respondents, the findings may well have turned out to be different than the ones reported in this research. Thus it is recommended that future research in this area should be conducted by using performance and OCB data, which is based on supervisory ratings of employees. 
Secondly the data for this study was collected from faculty members teaching in universities across five major cities of Pakistan. The generalizability of the findings of this study to other contexts may thus be limited. In other words it could be that the findings obtained from the present sample are specific only to the context under study here. In this regard, it would be useful to replicate this study under different settings to establish the validity and generalizability of the present findings across different contexts.

Finally the data in this study was collected through self-reports, which creates the potential for common-method variance (Podsakoff et al., 2003). One important concern in such cases is that common method variance may artificially inflate observed relationships between variables. This however might not be a problem because research has shown that the concern about common method bias has no empirical basis (Spector, 1987). Still I performed the Harman's single factor test (Podsakoff et al., 2003) to see if common method variance was a problem in the present study. If common method variance existed, a single factor would emerge from a factor analysis of all the measurement items, or one general factor that accounted for most of the variance would result. The factor analysis revealed 13 factors with eigen values greater than 1.0 that accounted for $64.2 \%$ of the total variance. The first factor accounted for only $20.3 \%$ of the variance. These results suggested that common method variance was not a serious problem in the present study.

\section{Conclusion}

The main aim of this research was to study the effects of job involvement on in-role and extra role performance. Generally studies attempting to uncover a positive relationship between job involvement and performance have met with limited success (Brown, 1996). This study adds to the literature by empirically demonstrating that job involvement can predict both in-role and extra role performance. In addition, prior research has demonstrated that job involvement also leads to more positive attitudes and behaviours such as increased organizational commitment (Brown, 1996), a lower cognition to turnover (Huselid and Day, 1991) and reduced absenteeism (Harrison \& Martocchio, 1998). Thus fostering high levels of job involvement among employees can be an effective strategy to increase both forms of performance and to foster more positive attitudes and behaviours. Therefore investing in conditions, which help to make employees more involved in their jobs, is likely to be important for the growth and profitability of the organizations.

\section{References}

Ashforth, B.E., and Saks, A.M. (1996). Socialization tactics: Longitudinal effects on newcomer adjustment. Academy of Management Journal, 27, 95-112.

Baron, R.M., \& Kenny, D.A. (1986). The moderator-mediator variable distinction in social psychological research: Conceptual, strategic and statistical considerations. Journal of Personality and Social Psychology, 51, 1173-82.

Bateman, T.S., and Organ, D.W. (1983). Job satisfaction and the good soldier: The relationship between affect and employee citizenship. Academy of Management Journal, 26, 587-595.

Blau, G.J., Boal, K.B., (1987). Conceptualising how job involvement and organizational commitment affect turnover and absenteeism. The Academy of Management Review, 12, 288-300.

Blau, P.M. (1964). Exchange and power in social life. New York: Wiley 
Bolger, R., \& Somech, A. (2004). Influence of teacher empowerment on teachers organizational commitment, professional commitment and organizational citizenship behavior in schools. Teaching and Teacher Education, 20, 277-289.

Borman, W.C., \& Motowidlo, S.J. (1997). Task performance and contextual performance: The meaning for personnel selection research. Human Performance, 10, 99-109.

Brown, S.P., \& Leigh, T.W. (1996). A new look at psychological climate and its relationship to job involvement, effort and performance. Journal of Applied Psychology, 81, 358-368.

Brown, S.P. (1996). A meta-analysis and review of organizational research on job involvement. Psychological Bulletin, 120, 235-255.

Chu, C., Lee, M., Hsu, H. and Chen, I. (2005). Clarification of the antecedents of hospital nurse organizational citizens hip behaviour - an example from a Taiwan regional hospital. Journal of Nursing Research, 13, 313-324.

Cohen, A,. \& Vigoda, E. (2000). Do good citizens make good organizational citizens? An empirical examination of the relationship between general citizenship and organizational citizenship behavior in Israel. Administration and Society, 32, 596625.

Cohen, A. (1999). Relationships among the five forms of commitment: an empirical analysis", Journal of Organizational Behaviour, 20, 285-308.

Cohen, A. (2000). The relationship between commitment forms and work outcomes: A comparison of three models. Human Relations, 53, 387-417.

Cron, W.L. (1984). Industrial salesperson development: A career stages perspective. Journal of Marketing, 48, 41-52.

Diefendorff, J., Brown, D., Kamin, A., and Lord, B. (2002). Examining the roles of job involvement and work centrality in predicting organizational citizenship behaviours and job performance. Journal of Organizational Behaviour, 23, 93108.

Dubinsky, A.J., and Hartley, S.W. (1986). A path-analytic study of a model of salesperson performance. Journal of the Academy of Marketing Science, 4, 3646.

Farh, J.L., Earley, P.C., and Lin, S.C. (1997). Impetus for action: A cultural analysis of justice and organizational citizens hip behaviour in Chinese society. Administrative Science Quarterly, 42, 421-44.

Hackman, J.R., \& Lawler, E.E. (1971). Employee reactions to job characteristics. Journal of Applied Psychology, 55, 259-286.

Harrison, D.A., and Martocchio, J.J. (1998). Time for absenteeism: A 20-year review of origins, offshoots and outcomes. Journal of Management, 24, 305-350.

Huselid, M.A., and Day, N.A. (1991). Organizational commitment, job involvement and turnover: A substantive and methodological analysis. Journal of Applied Psychology, 76, 380-391. 
Janis, N.A. (1989). Organizational commitment, career factors and career/life stage. Journal of Organizational Behaviour, 10, 247-266.

Kanungo, R.N. (1982a). Measurement of job and work involvement. Journal of Applied Psychology, 77, 341-9.

Kanungo, R. (1982b). Work alienation: An integrative approach. New York: Wiley

Katz, D., \& Kahn, R.L. (1978). The Social Psychology of Organizations. New York: Wiley.

Knoop, R. (1986). Job involvement: An elusive concept. Psychological Reports, 59, 451-456.

Konovsky, M.A., \& Cropanzano (1991). Perceived fairness of employee drug testing as a predictor of employee attitudes and job performance. Journal of Applied Psychology, 76, 698-707.

Lassk, F., Marshall, G., Cravens, D., and Moncrief, W. (2001). Salesperson job involvement: a modern perspective and a new scale. Journal of Personal Selling and Sales Management, 21, 291-302.

Lawler, E.E. (1986). High involvement management: participative strategies for improving organizational performance. San Francisco: Jossey-Bass.

Lodahl, T., and Kejner, M. (1965). The definition and measurement of job involvement. Journal of Applied Psychology, 49, 24-33.

Loui, K. (1995). Understanding employee commitment in the public organization: A study of the juvenile detention center. International Journal of Public Administration, 18,1269-1295.

Meyer, J.P., Paunonen, V., Gellatly, I.R., Goffin, R.D., and Jackson, D.N. (1989). Organizational commitment and job performance: It's the nature of the commitment that counts. Journal of Applied Psychology, 74, 152-156.

Mowday, R.T., Porter, L.W., and Steers, R.M., (1982). Employee-organization linkages: the psychology of commitment, absenteeism and turnover. New York: Academic Press.

Munene, J.C. (1995). Not on seat: An investigation of some correlates of organizational citizenship behaviour in Nigeria. Applied Psychology: An International Review 44, $111-22$.

Nunnaly, J.C. \& Bernstein, I.H. (1994). Psychometric theory. New York: McGraw-Hill.

Organ, D.W., \& Ryan, K. (1995). A meta-analytic review of attitudinal and dispositional predictors of organizational citizenship behaviour. Personnel Psychology, 48, 775-800.

Organ, D.W. (1988). Organizational citizenship behavior. Lexington: D.C. Heath and Co.

Paullay, I., Alliger, G., and Stone-Romero, E. (1994). Construct validation of two instruments designed to measure job involvement and work centrality. Journal of Applied Psychology, 79, 224-8. 
Pfeffer, J. (1994). Competitive advantage through people. Boston: Harvard Business School Press.

Podsakoff, P.M., Mackenzie, S.B., Lee, J.L., Podsakoff, N.P. (2003). Common method biases in behavioural research: A critical review of the literature and recommended remedies. Journal of Applied Psychology, 88, 879-903.

Podsakoff, P.M., Mackenzie, S.B., Moorman, R.H., \& Fetter, R. (1990). Transformational leader behaviours and their effects on followers trust in leader, satisfaction, and organizational citizenship behaviours. Leadership Quarterly, 1, $107-142$.

Rabinowitz, S., \& Hall, D.T. (1977). Organizational research on job involvement. Psychological Bulletin, 84, 265-288.

Rabinowitz, S., \& Hall, D.T. (1981). Changing correlates of job involvement in three career stages. Journal of Vocational Behaviour, 18, 138-144.

Rotenberry, P.F., \& Moberg, P.J. (2007). Assessing the impact of job involvement on performance. Management Research News, 30, 203-215.

Saal, F.E. (1978). Job involvement: A multivariate approach. Journal of Applied Psychology, 63, 53-61.

Sekaran, U. (1989). Paths to the job satisfaction of banking employees. Journal of Organizational Behaviour, 10, 347-359.

Sekeran, U., \& Mowday, R.T. (1981). A cross cultural analysis of the influence of individual and job characteristics on job involvement. International Review of Applied Psychology, 30, 51-64.

Skarlicki, D., Latham, G. (1995). Organizational citizenship behaviour and performance in a university setting. Canadian Journal of Administrative Sciences, 12, 175-81.

Somers, M.J. \& Birnbaum, D. (1998). Work-related commitment and job performance: it's also the nature of the performance that counts. Journal of Organizational Behaviour, 19, 621-34.

Spector, P.E. (1987). Method variance as an artifact in self-reported affect and perceptions at work: Myth or significant problem. Journal of Applied Psychology, $72,438-443$.

Yousef, D.A. (1998). Satisfaction with job security as a predictor of organizational commitment and job performance in a multicultural environment. International Journal of Manpower, 19, 184-194.

Zikmund, W.G. (2003). Business research methods. Ohio: Thomson South-Western. 